description, are provided by Waldo Maitland. Some very striking effects, produced by flood-lighting trees, are shown. "Roof-gardens, the Lungs of the Future" are given adequate treatment in an article by Lady Allen of Hurtwood, who introduces many practical suggestions. One might advance the suggestion that the 'extremely small spaces' such as are included with the majority of present-day houses might receive adequate treatment in future numbers, though the editor seems to be alive to this need. A study of the development of the 'garden city' is promised for the next number (July).

\section{Research on Oranges and Related Crops}

The British South Africa Co. has issued a report on the activities of the Mazoe Citrus Experimental Station up to the end of 1932 (Oxford Univ. Press, 192 pp.). The Director, Dr. W. J. Hall, and Mr. W. K. Ford are engaged in a study of the citrus insects of Southern Rhodesia, and publish detailed descriptions of a considerable number of pests. Soils of the Mazoe Estate are under investigation by Dr. A. A. Morris, who contributes a paper on the relation between soils and field practices. Special attention has been devoted to irrigation, cover crops and manures. Problems of artificial coloration, maturity and transport wastage of oranges have engaged the attention of Mr. G. R. Bates. The work of the Station is comparatively recent, but the various problems are being studied with a detail which should ensure the production of valuable results.

\section{Electrical and Magnetic Units}

Bulletin No. 93 of the National Research Council, Washington, reproduces the papers on units presented before the American Section of the International Union of Pure and Applied Physics at Chicago in June last. After discussion it was recommended :-that in view of the long use of the classical centimetre-gram-second units, no change should be made at present, but that the Gaussian system should be considered in future; that the practical units-ohm, volt, ampere, coulomb, farad, henry, joule and watt-might be extended into a complete absolute system either through the metre-kilogramsecond or the centimetre-10 $10^{7}$ gm.-second, the former by preference. These proposals will in due course be considered by the Committee on Symbols, Units and Nomenclature established by the Inter. national Union.

\section{Health of the British Army during 1932}

Lieut.-Gen. H. B. Fawcus, director-general of the Army Medical Services, states that the health of all ranks throughout 1932 was satisfactory ("Report on the Health of the Army for the Year, 1932". London: H.M. Stationery Office, 1934. 2s. 6d. net). The admission rate to hospital, 412.5 per 1,000 of the strength, was the lowest on record, and the invaliding and constantly sick rates were also the lowest recorded since the War. All the more important diseases have shared in the decline, namely, malaria, dysentery, influenza, tonsillitis, venereal diseases and others. In consequence of the high incidence of tonsillitis over many years, a Joint Medical Services Committee has studied the subject, but without reaching any very definite conclusion as to causation or prevention. A summary of research work is given in the report.

\section{German Exhibition of Chemical Plant}

"AснемA" is the Ausstellung für chemisches Apparatewesen, the seventh of which is to be held at Cologne on May 18-27 under the auspices of "Dechema", the Deutsche Gesellschaft für chemisches Apparatewesen. In anticipation of this exhibition the Achema-Jahrbuch 1931/1934, a report of some 230 pages on the position and development of the study and construction of chemical plant, has recently been published by Dechema at Seelze bei Hannover. Those who are interested in the exhibition and apply before May 10 can obtain a copy of the Jahrbuch, which is priced at $10 \mathrm{~m}$., on sending only $0.40 \mathrm{~m}$. to cover the cost of postage. The "Wissenschaftlicher Teil" includes articles on the development of technique and plant construction, on standards in apparatus, on welding in the building of chemical plant, on instruments for the measurement of therapeutically active ultra-violet light emission, and on the Drawinol process for dehydrating ethyl alcohol. The "Technisch-industrieller Teil" contains information concerning constructional materials, laboratory apparatus, technical apparatus, plant and machinery. The book serves also as a guide to the exhibits. We are reminded that in describing the sixth exhibition held at Frankfurt-am-Main in 1930 we said that there could never have been a more comprehensive show of aids to chemical manipulation; at Cologne 300 firms will exhibit more than 2,000 types of apparatus and plant, so that the forthcoming exhibition is unlikely to be less valuable and impressive.

\section{Congress of History of Medicine}

THE International Society of the History of Medicine has received an official invitation from the Spanish Government to hold its tenth congress at Madrid in the second fortnight of September 1935. The following subjects, of which the executive committee has to select two, have been suggested for discussion: Spanish colonial medicine; Pre-Columbian medicine; the history of syphilis ; medical folk-lore, and the introduction of biological ideas into the domain of history, a subject proposed by Prof. E. Jeanselme of Paris. This Congress of 1935 must not be confused with that organised by the International Academy of the History of Sciences, which will be held this year at Barcelona, Madrid, Toledo, Coimbra and Lisbon, on September 19October 2.

\section{Television Inquiry}

The Postmaster-General stated in the House of Commons on April 30 that he hoped to announce shortly the composition of a committee which will advise on the conditions under which any public 